Received: September 7, 2018

Revision received: November 6, 2018

Copyright () 2019 ESTP

Accepted: November 10, 2018

www.estp.com.tr

DOI 10.12738/estp.2019.1.0269 • February 2019 • 19(1)•78-94

Article

\title{
Improvement of Preservice Turkish Teachers' Perceived Writing Self-Efficacy Beliefs
}

\author{
İbrahim Seçkin Aydın ${ }^{1}$ \\ Dokuz Eylül University
}

\begin{abstract}
The concept of self-efficacy is built upon the theory of Social Cognitive Learning by Bandura. Based on this theory, one could posit that an individual's belief on his/her self-efficacy at any given subject is of high importance. A body of research shows that people with high self-efficacy levels have higher performance levels. In parallel to this, writing self-efficacy perception describes the belief one has in his/her writing skills. In this scope, this study aimed to determine the improvement of self-efficacy perceptions of preservice Turkish teachers on their writing skills during undergraduate education. The study group consisted of 94 preservice teachers. For the research, conducted based on the mixed methods research, quantitative data were collected both at the beginning and end of the undergraduate program, followed by collection of qualitative data through open-ended questions posed to 39 participants. The results of the analyses revealed that the perception of preservice Turkish teachers on their writing self-efficacy improved throughout the education they had received, that they showed progress in items of prewriting and draft; and that however there was no significant difference in revising and editing, i.e. one of the most important processes in writing. The responses provided by the participants to the open-ended questions also proved this argument to be true. Seeing that the participants did not make any considerable progress in revising and editing process at the end of the undergraduate education is an important indication that there exist challenges in both language learning and teaching and that preservice teachers cannot develop an adequate level of awareness on this process.
\end{abstract}

\section{Keywords}

Self-efficacy $\bullet$ Writing self-efficacy $\bullet$ Writing process $\bullet$ Writing instruction $\bullet$ Preservice Turkish teachers

${ }^{1}$ Correspondence to: İbrahim Seçkin Aydın, Turkish Language Education, Buca Education Faculty, Dokuz Eylül Universty, Turkey. Email: se.aydin@windowslive.com

Citation: Aydın, I. S. (2018). Improvement of Preservice Turkish Teachers' Perceived Writing Self-Efficacy Beliefs. Educational Sciences: Theory \& Practice, 19(1), 78-94. http://dx.doi.org/10.12738/estp.2019.1.0269 
Writing is at the forefront among the most demanding skills to acquire, both in native and foreign languages. Writing skill, being a combination of complex tasks and attitudes (Harrington, Holik \& Hurt, 1998), comprises cognitive and metacognitive processes in itself. According to some researchers (Güneş, 2013; Turan, 2010), the text to be written is conceptualized in mind before it is actually conveyed in text. The mind arranges feelings and ideas about a subject through restricting, classifying and sorting and these feelings and ideas are then put onto a paper based on certain rules. Such steps entail authors to use various strategies in text production. As argued by Flower, Hayes, Carey, Schriver and Stratman (1986), good authors regularly monitor themselves and carry out numerous self-assessments by reviewing not only the text they create but their own writing strategies and themselves as authors.

Cognitive component of writing has been a subject of many researches in the relevant literature for a very long time. These researches focused on the followings: time allocated for cognitive efforts and tasks in writing process (Kellog, 1987); the strategies and methods in revision of diverse text types (Piolat \& Roussey, 1991); the reasons why authors and editors are unsuccessful in detecting and correcting the mistakes in the texts (Plumb, Butterfield, Hacker \& Dunlosky, 1994); environmental, cognitive and metacognitive influences in text revision (Butterfield, Hacker \& Albertson, 1996) and performances in planning, translation and revision of metacognitive knowledge related to cognitive tasks in writing (Berninger, Whitaker, Feng, Swanson \& Abbott, 1996).

Metacognitive concept has emerged with the interest shown in the theory of social learning theory beginning from 1970s. This concept was rediscovered as the monitoring of thinking processes, mostly based on Flavell's ideas $(1976 ; 1978 ; 1981 ; 1982 ; 1999 ; 2004)$. As stated by cognitive psychologists, metacognition is defined as the knowledge and control that a person has on his/her thinking and learning (Strassman, 1997) and as understanding, using and controlling one's own cognitive processes (Reeve \& Brown, 1985). This approach has paved the way towards a belief that metacognition needs to be examined and regulated not only in learning domains, but also in every case where one's knowledge is referred to, including in areas where writing skills are addressed. Reeve \& Brown (1985), Jones and Pellegrini (1996) argue that authors, who are talented and experienced in writing that necessitates a high-level mental performance and encompasses both cognitive and metacognitive processes, understand whether they and their readers have attained the set goals. At this stage, writing can also be perceived as a tool that plays a role in the development of metacognition as it activates reflective thinking skill. On the other hand, however, one's ability to do self-assessment depending on his/her self-awareness is indicative of his/her cognitive and metacognitive experiences in writing. It could be posited that in writing-related contexts, cognition refers to the knowledge to be used in the writing process, whilst metacognition refers to the way this knowledge would be used. Self-efficacy perception reveals how a person perceives himself/herself in terms of cognitive and metacognitive efficacy.

\section{Writing and Self-Efficacy}

Although the concept of self-efficacy is based upon the theory of Social Cognitive Learning by Albert Bandura, the theoretical basis of writing self-efficacy rests on the opinions and analyses of researchers such as Zimmerman and Bandura (1994), Pajares (2003), Schunk (2003). Researches on writing self-efficacy which date back to the mid-1980s showed correlation between writing self-efficacy and a wide array of variables 
(writing quality and standards, writing anxiety etc.) and shed light on the correlation levels in different groups (grade level, gender etc.) and the possible reasons for high/low self-efficacy levels according to writing performance (Bruning, 2013).

People create self-efficacy perception through interpretation of their own performance or mastery, observation of others' actions and social comparisons made with other experienced people (Pajares, 2003). According to Schunk (2003), those who feel more effective whilst learning or performing a task can tackle challenges more, can show more resistance to problems and attain a higher level of success when compared to students who are doubtful of their learning talents. Therefore, improvement in writing self-efficacy can be accepted as an important variable in coming over possible bottlenecks that students may face in writing.

The studies show that writing is, in principle, a process-driven act requiring complex cognitive/metacognitive skills and that some practices entailing certain efforts in different stages of education beginning from primary school to university improve these skills (Bayat, 2014) and increase the level of writing self-efficacy (Abrami \& Barrett, 2005; Cole, Ryan, \& Kick, 1995; Nicolaidou, 2012; Xu, Park \& Baek, 2011; Walker, 2003). Moreover, the study field related to the person's motivation to write from a cognitive dimension is, again, mostly centered on self-efficacy (MacArthur, 2016).

\section{Purpose}

This study primarily aimed to investigate the status of writing self-efficacy perceptions of preservice Turkish teachers at the beginning and end of their education, who will be engaged in language teaching and learning processes. In addition, the study also inquired into the knowledge and experiences acquired by the preservice teachers in writing throughout their education as well as unattained gains and their opinions as to why these gains were not achieved. In undergraduate education, preservice Turkish teachers receive a wide range of theoretical and applied lessons, especially on written expression and writing. In this sense, preservice training -where these lessons are put into practice- plays an important role for self-efficacy perception of these teachers. Writing requires certain cognitive processes so that it can be improved (Ülper \& Uzun, 2009) and therefore development and teaching of this skill bears some challenges. The findings obtained from the study group who took part in this research reveal that preservice teachers should make use of their expertise for improving writing self-efficacy and solving the potential problems they may encounter throughout their career. In view of the above, answers were sought to the following questions:

i. Is there a significant difference between the writing self-efficacy perception scores the preservice teachers acquired from pretest and posttest?

ii. Is there a significant difference between the writing self-efficacy perception scores the preservice teachers acquired from pretest and posttest in (1) prewriting, (2) draft, (3) revising and editing? 
iii. What are the opinions of preservice teachers on
a) the gains they acquired
b) the type of the inefficacy experienced
c) the reasons of their inefficacy

throughout their education?

\section{Method}

This research was conducted with a view to determining the improvement levels of writing self-efficacy perceptions of preservice Turkish teachers in the study group at the beginning of their education and right before their graduation as well as their opinions on this process. Mixed method was administered in the research, integrating both qualitative and quantitative data so as to obtain more sound data on writing self-efficacy perceptions of preservice teachers. Mixed methods require combining or integrating qualitative and quantitative research findings (Creswell, 2016). As for the research model, Explanatory Sequential Design was used. This model allows the researcher to first conduct the quantitative study and to analyze the results and builds to the subsequent quantitative phase where the researcher further elaborates on the findings. As this method explains first the quantitative data and then the qualitative data, it is called explanatory; and as it envisages a stage where quantitative phase informs the follow-up qualitative phase, it is called sequential (Creswell, 2016).

The research involved preservice Turkish teachers studying at Dokuz Eylül University Buca Faculty of Education and was carried out in two stages. The quantitative data in the research were collected from 97 participants (50 female, 47 male) in their first year in 2013 and from 94 participants (50 female, 44 male) in their last year in 2017. The three participants were excluded from the data set as they did not participate in the last implementation. Following the acquisition of quantitative data, 39 (20 female, 19 male) volunteering preservice teachers from the same participant group were administered interview form to collect the qualitative data.

The study employed 54-item Writing Self-Efficacy Perception Scale (WSPS) developed by Aydın, İnnalı, Batar and Çakır (2013) as a quantitative data collection tool as well as a semi-structured "Self-Assessment Interview Form for Writing" to collect qualitative data.

Writing Self-Efficacy Perception Scale (WSPS): WSPS is comprised of three factors. These factors are "Prewriting", "Draft" and "Revising and Editing". The first factor explains 7.2\% (12 items; Prewriting) of the total variance, the second factor explains 33.6\% (33 items; Draft) of the total variance, and third factor explains $3.9 \%$ (9 items; Revising and Editing) of the total variance. It was observed that factor load values at item level varied between .42 and .68 in "Prewriting", between .37 and .67 in "Draft" and between .60 and .81 in "Revising and Editing". The first factor was calculated as .88 Cronbach alpha coefficient, the second factor as .96 and the third factor as .89. The scale had an overall of .96 alpha coefficient (Aydın, İnnalı, Batar \& Çakır 2013). 
Self-Assessment Interview Form for Writing: Self-Assessment Interview Form for Writing is comprised of three open-ended questions. These questions were prepared with the aim to reveal (1) the gains acquired in writing by the participant group during their undergraduate education, (2) the situations where they felt inefficient and (3) the reasons as to their inefficacy, by taking into account the improvement in their writing self-efficacies. Factors of quantitative measurement tools were taken into account during the preparation of the questions and the scope, objective and limitations of the study were paid regard to; the opinions of two expert lecturers in Turkish Language Education and a lecturer from the field of Measurement and Assessment were consulted. The experts agreed on the scope, objective and limitations of the study.

Before carrying out the analyses, missing values, extreme values and appropriateness of sample size were examined. Missing values in the data set were assigned an average value. There were no extreme values in the data set. Normal distribution of the scores was examined to decide on the technique to employ so as to determine the differences between the scores the students obtained in the pretest and posttest of WSPS and the results are presented in Table 1.

Table 1

Test Results on the Normal Distribution

\begin{tabular}{llllc}
\hline \multirow{2}{*}{ Test } & \multicolumn{3}{c}{ Kolmogorov-Smirnov } \\
\cline { 3 - 5 } & & KS & sd & p \\
\hline \multirow{2}{*}{ WSPS } & pre & .088 & 94 & .071 \\
& post & .049 & 94 & .200 \\
\hline \multirow{2}{*}{ pos }
\end{tabular}

$N=94$; Pretest: $p>.05$, Posttest: $p>.05$

When Table 1 is examined, it can be seen that the scores acquired by the students in both pretest and posttest comply with the normal distribution. Based on this finding, the difference was calculated with $t$ test.

Normal distribution of the scores was examined in order to decide on the technique to employ so as to determine the differences between the WSPS scores the students obtained in prewriting, draft and revising and editing factors according to the year they are in and the results are presented in Table 2.

Table 2

Test Results on the Normal Distribution of Sub-factors

\begin{tabular}{lcccc}
\hline \multirow{2}{*}{ Sub-Factors } & \multirow{2}{*}{ Year } & \multicolumn{3}{c}{ Kolmogorov-Smirnov } \\
\cline { 2 - 5 } Prewriting & 1 & .089 & Kd & p \\
\hline \multirow{2}{*}{ Draft } & 4 & .075 & 94 & .063 \\
& 1 & .113 & 94 & $.000^{*}$ \\
\hline \multirow{2}{*}{ Revising and Editing } & 4 & .058 & 94 & $.200^{*}$ \\
& 1 & .119 & 94 & .002 \\
& 4 & .108 & 94 & .007 \\
\hline
\end{tabular}

When Table 2 is analyzed, it is observed that the scores obtained by the students in different year-levels in prewriting comply with the normal distribution and that, however, the scores they obtained in draft and revising and editing do not comply with the normal distribution. Based on this finding, to calculate the difference, t-test was used in prewriting, whereas Mann Whitney $U$ tests were used in draft and revising and editing. 
The qualitative data in the research were collected through asking the following questions:

i. What are the gains you acquired in writing during your education (prewriting, draft and revising and editing)?

ii. What are the situations where you felt inefficient in writing (prewriting, draft, and revising and editing)?

iii. What are the reasons of the inefficacies experienced in writing?

Content analysis, i.e. one of the qualitative research methods, was used for the analysis of the obtained data. The situation determination that allowed for a thorough examination of the data constituted the pattern of the research. The questions in the research were prepared based on the relevant body of literature and expert opinions. The options provided to the participants in the interview form were firstly coded for each question and then combined under main headings (category) with semantic consistency. For the determination and classification of codes, the qualitative research program (QSR Nvivo Plus 11 for Windows package program) was used. The determined codes were then transferred together with the sentences they were assigned to into the computer program and their frequency values were detected.

In analyzing the study data, and forming and interpreting the categories, the opinions of two different experts besides the researcher were consulted and thus the reliability of the research was ensured. For the reliability calculation, the inter-rater agreement formula by Miles and Huberman (Reliability Coefficient = Number of Agreements + Number of Disagreements X 100) was utilized. The expected rate of agreement among coders should at least be $80 \%$ according to the coding with internal consistency (Miles \& Huberman, 1994; Patton, 2002). The calculated value of $98 \%$ in the scope of this research shows that there is a high level of consistency between coders.

\section{Findings}

The results of $t$ test conducted in order to reveal whether there was any statistically significant difference among the scores obtained by the participants in the WSPS pretest and posttest are presented in Table 3 .

Table 3

Difference between WSPS Pretest and Posttest

\begin{tabular}{llllllll}
$\begin{array}{l}\text { Pretest- } \\
\text { Posttest }\end{array}$ & Test & N & Average & Std. Dev. & t & sd & p \\
\hline \multirow{2}{*}{ WSPS } & Pre & 94 & 198.5745 & 21.44334 & 2.705 & 189 & $.007^{*}$ \\
\hline
\end{tabular}
$N=94, * * p<.01$

When Table 3 is examined, it is observed that the scores obtained by the students from the posttest $(\bar{X}=$ $207.7)$ in the entire scale are, in statistical terms, significantly higher than those obtained in pretest $\left(\mathrm{t}_{(189)}=2.705\right.$, $p<0.05)$. Table 4 shows the results of the t test administered to reveal whether there was any statistically significant difference between the pretest and posttest scores obtained by the preservice teachers in WSPS prewriting stage. 
Table 4

Difference between the Scores Obtained in Prewriting Stage

\begin{tabular}{lccccccc}
\hline Prewriting Sage & Test & $\mathbf{N}$ & Average & Std. Dev. & t & sd & p \\
\hline \multirow{2}{*}{ Prewriting } & $\mathbf{1}$ & 94 & 43.1064 & 6.35249 & 2.558 & 189 & .011 \\
& $\mathbf{4}$ & 94 & 45.3622 & 5.83166 & & & \\
\hline
\end{tabular}

$N=94, * * p<.05$

When Table 4 is analyzed, it is seen that there is a statistically significant difference between the scores obtained by the students in their first and fourth years in WSPS prewriting $\left(\mathrm{t}_{(189)}=2.558, p<0.05\right)$. According to the table, the scores obtained by the students in WSPS prewriting stage right before graduation are, in statistical terms, significantly higher than those obtained in the first year.

Table 5 presents the results of the Mann Whitney $U$ tests conducted in order to reveal whether there is any statistically significant difference between the pretest and posttest scores obtained by the preservice teachers in WSPS draft and revising and editing.

Table 5

Difference between the Scores obtained in Draft and Revising and Editing Stages

\begin{tabular}{lcccccc}
\hline Draft-Revising and Editing & Year & $\mathbf{N}$ & Mean Rank & Total Rank Sum & $\mathbf{U}$ & $\mathbf{p}$ \\
\hline \multirow{3}{*}{ Draft } & 1 & 94 & 81.96 & 7704.00 & 3239.000 & $.001 *$ \\
& 4 & 94 & 109.61 & 10632.00 & & \\
\hline \multirow{3}{*}{ Revising and Editing } & Total & 191 & & & & \\
& 1 & 94 & 95.77 & 9002.00 & 4537.000 & .954 \\
& 4 & 94 & 96.23 & 9334.00 & & \\
\hline
\end{tabular}

$N=94$, Draft: $* * p<.01$; Revising and Editing: $p>.05$

When Table 5 is reviewed, it is seen that there is a statistically significant difference between the scores obtained by the students in their first and fourth years in WSPS draft $(U=3239, \mathrm{p}<0.05)$. It is observed that the scores obtained by the students in WSPS prewriting prior to graduation are, in statistical terms, significantly higher than those obtained in the first year. However, it is seen that there is no statistically significant difference between the scores obtained in the first and last years in WSPS revising and editing scores obtained (U=4537, $p>0.05)$.

During the qualitative research, the participants were first asked the question "What are the gains you acquired in writing during your education" and the answers obtained were analyzed and the results are presented in Table 6.

In the content analysis made in view of the feedbacks received from the participants, three categories were formed as "prewriting", "draft" and "revising and editing". The writing process was then subcategorized under the headings of "techniques of expression", "style", "grammar" and "content".

The majority of the preservice teachers stated that they did research on the relevant subject and used sources $(f=20)$. Among these participants there were those who said that they went through various papers as well as books about the content and did the research in digital environment. 16 preservice teachers in the participant group noted that they also developed a writing plan during the process of prewriting. Those who stated that they 
had prepared a plan suggested that the reason for having developed a plan was to determine how to narrate the subject prior to writing and that they wrote the text based on this plan.

Table 6

Gains Acquired in Writing

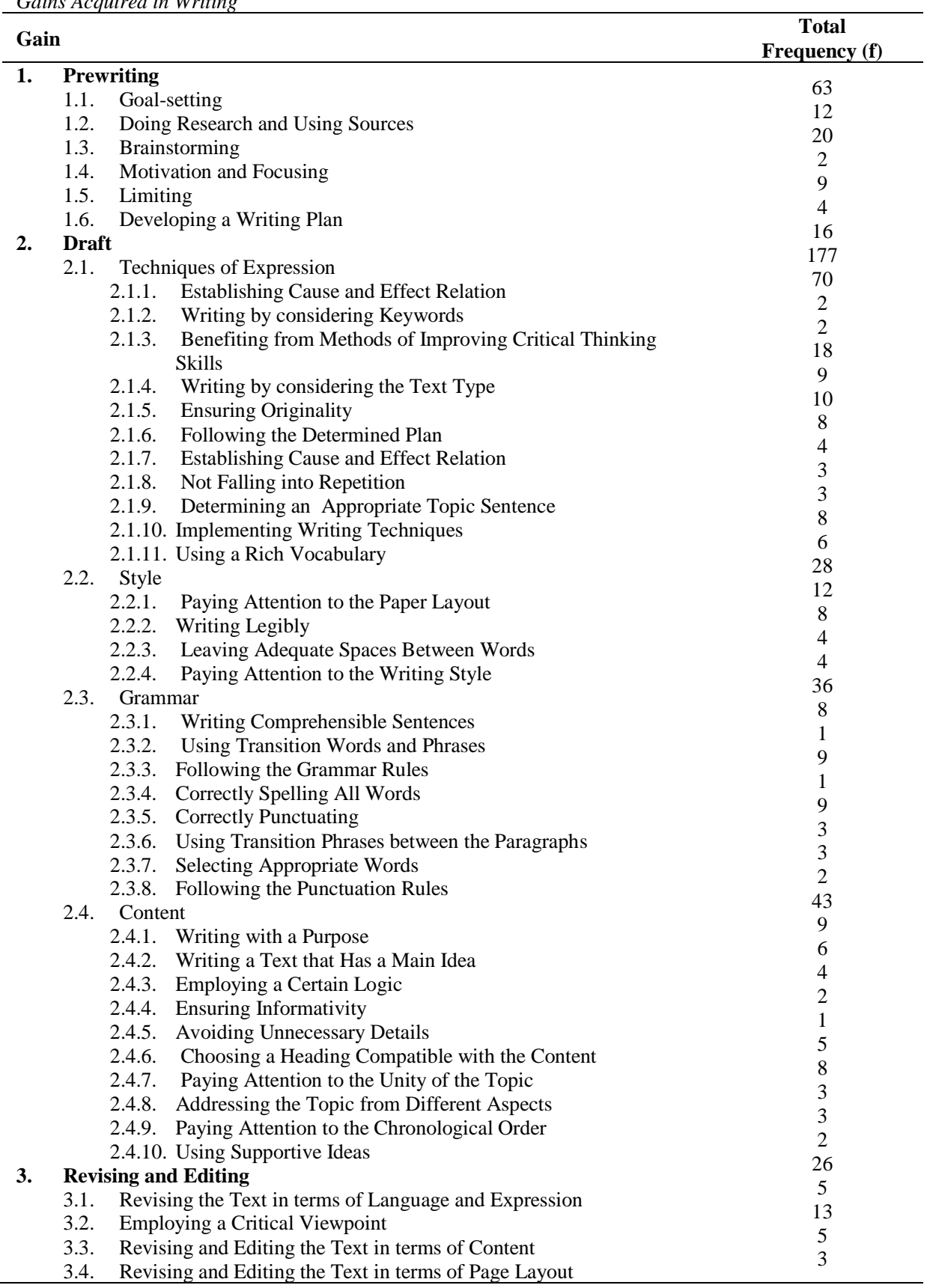


Table 7

Inefficacies in writing

\begin{tabular}{|c|c|c|}
\hline \multicolumn{2}{|c|}{ Gain } & Total frequency (f) \\
\hline \multirow[t]{6}{*}{1.} & Prewriting & 22 \\
\hline & 1.1. Doing Research and Using Sources & 4 \\
\hline & 1.2. Brainstorming & 1 \\
\hline & 1.3. Motivation and Focusing & 3 \\
\hline & 1.4. Developing a Writing Plan & 8 \\
\hline & 1.5. Limiting & 6 \\
\hline \multirow[t]{30}{*}{2.} & Draft & 103 \\
\hline & 2.1. Techniques of Expression & 58 \\
\hline & 2.1.1. Writing Fluently & 2 \\
\hline & 2.1.2. Considering Keywords & 1 \\
\hline & 2.1.3. Benefiting from Methods of Improving Critical Thinking & 15 \\
\hline & Skills & 17 \\
\hline & 2.1.4. Writing by considering the Text Type & 8 \\
\hline & 2.1.5. Ensuring Originality & 2 \\
\hline & 2.1.6. Following the Determined Plan & 6 \\
\hline & 2.1.7. Not Falling into Repetition & 2 \\
\hline & 2.1.8. Determining an Appropriate Topic Sentence & 2 \\
\hline & 2.1.9. Implementing Writing Techniques & 7 \\
\hline & 2.1.10. Using a Rich Vocabulary & 20 \\
\hline & 2.2. Style & 8 \\
\hline & 2.2.1. Paying Attention to the Paper Layout & 2 \\
\hline & 2.2.2. Writing Legibly & 1 \\
\hline & 2.2.3. Leaving Adequate Spaces Between Words & 9 \\
\hline & 2.2.4. Paying Attention to the Writing Style & 17 \\
\hline & 2.3. Grammar & 2 \\
\hline & 2.3.1. Paying Attention to Avoid Incoherency & 1 \\
\hline & 2.3.2. Using Transition Words and Phrases & 4 \\
\hline & 2.3.3. Following the Grammar Rules & 5 \\
\hline & 2.3.4. Correctly Punctuating & 3 \\
\hline & 2.3.5. Using Transition Phrases between the Paragraphs & 2 \\
\hline & 2.3.6. Following the Punctuation Rules & 6 \\
\hline & 2.4. Content & 3 \\
\hline & 2.4.1. Paying Attention to the Unity of the Topic & 1 \\
\hline & 2.4.2. Addressing the Topic from Different Aspects & 1 \\
\hline & 2.4.3. Using Supportive Ideas & 1 \\
\hline & 2.4.4. Choosing a Heading Compatible with the Content & 7 \\
\hline \multirow[t]{4}{*}{3.} & Revising and Editing & 3 \\
\hline & 3.1. Improving Thinking Skills & 2 \\
\hline & 3.2. Employing a Critical Viewpoint & 2 \\
\hline & 3.3. Sharing Observations and Experiences & \\
\hline
\end{tabular}

For "draft" stage, "benefiting from methods of improving critical thinking skills" ( $f=18)$, ensuring originality $(f=10)$ and writing by considering the text type $(f=9)$ were listed to be among the most used gains in terms of techniques of expression. The participants, who said that they used the methods of improving critical thinking skills, pointed out that they determined a technique of expression suitable to their subject and supported their texts through using subjective-objective statements, adopting literary language and presenting examples and evidence etc.

Those who wrote by paying attention to the page layout $(f=12)$ in terms of style said that they exercised due diligence to the neatness of the paper and its physical appearance and emphasized that they took into account 
the language rules by following the grammar rules $(f=9)$, following the punctuation rules $(f=9)$ and writing comprehensible sentences $(f=8)$ and thus were able to write correctly.

As for content heading in draft stage, writing with a purpose $(f=9)$ was stated to be the most frequently used gain. The participants who internalized this gain underlined that they produced a text in line with the purpose they had defined in prewriting stage and that they strived to adhere to this purpose.

When "revising and editing" stage is examined, it is seen that the preservice teachers primarily gave the answer of employing a critical viewpoint $(f=13)$. They underlined the fact that employing a critical viewpoint was an important improvement for them, particularly in terms of thinking skills.

In view of the findings above, it is observed that participants created codes for "prewriting" ( $f=63)$, "draft" $(f=177)$ and "revising and editing" $(f=26)$.

During the collection of the qualitative data, the participants were asked the question "What are the situations where you felt inefficient in writing during your education?" and the answers were analyzed, and the results are presented in Table 7.

The inefficacies stated most frequently by the participants in the table were "developing a writing plan" $(f=8)$ and "limiting" $(f=6)$. The participants said that they did not know anything as to how they could develop a writing plan in prewriting process and that they had never done any work concerning this. The participants felt inefficient in terms of limiting, adding that they lack sufficiency in knowing how to limit a topic for creating a text.

The participants stated that the primary source of their inefficacy in draft in terms of techniques of expression was the failure in "writing by considering the text type" $(f=17)$. They said that they had problems in putting their ideas into paper (translating) as they were unable to create the text based on the criteria defined by different text types (article, story, essay etc.). Aside from these, among the most frequently observed inefficacies were "benefiting from methods of improving critical thinking skills" $(f=15)$ and "ensuring the originality" $(f=8)$. This opinion can also be linked to the problem that might have arisen from not paying attention to the text type. Taking into account the fact that every text type bears its own technique of expression, it could be asserted that these two coders are complementary of each other. Furthermore, these findings are consistent with the gains identified for writing in Table 6. That is, the preservice teachers who wrote by considering the text type benefited from the methods of improving critical thinking skills and; however, those who did not consider the text type whilst writing did not benefit from such methods. Almost half of the participants $(n=17)$ stated that they did not write by considering the text type, which is an indication that they lack the necessary text knowledge.

In "draft" process, codes with less frequency were used for style and grammar. Thus, it is seen that paying attention to the writing style $(f=9)$ and paying attention to the paper layout $(f=8)$ are correlated in terms of style and following the punctuation rules $(f=5)$ and following the grammar rules $(f=4)$ are correlated in terms of grammar. As for the content, the most frequently stated inefficacy was paying attention to the unity of the topic $(f=3)$. 
The participants stated that in "revising and editing" process they were inefficient in "improving thinking skills" ( $f=3)$, "employing a critical viewpoint" $(f=2)$ and "sharing observations and experiences" ( $f=2)$. Not discovering enough findings for this stage does not necessarily mean that the participants' self-efficacy is high in this stage; instead, this could be an indication of the fact that the preservice teachers primarily focus on prewriting and draft processes rather than the process of revising and editing.

It was determined that preservice teachers shared various opinions on the inefficacies experienced in the processes of prewriting $(f=22), \operatorname{draft}(f=103)$ and revising and editing $(f=7)$. When the gains acquired in writing were compared to the inefficacies experienced, it was observed that acquired gains had higher frequencies. However, although participants had acquired more gains for improving their self-efficacy perception, they were still inefficient in several aspects.

As a last step in the collection of qualitative data, the participants were posed the question of "What are the reasons of the inefficacies experienced in writing" and their answers were analyzed and the results are shown in Table 8.

\section{Table 8}

Reasons of the Inefficacies Experienced in Writing

\begin{tabular}{llc}
\hline Gain & & Total frequency (f) \\
\hline 1. & Prewriting & 47 \\
1.1. & Lack of Knowledge and Experience & 13 \\
1.2. & Lack of Motivation and Focusing & 2 \\
1.3. & Not Making Preparations & 5 \\
1.4. & Lack of Interest & 6 \\
1.5. & Lack of Reading Habit & 10 \\
1.6. & Not Developing a Writing Plan & 5 \\
1.7. & Not Allocating Time & 6 \\
Draft & & 37 \\
2.1. Not Trying & 7 \\
2.2. & Not Following the Grammar Rules & 6 \\
2.3. & Not Feeling Confident & 6 \\
2.4. & Not Following the Determined Plan & 5 \\
2.5. & Inability to Adjust the Writing Pace & 5 \\
2.6. & Inability to Use Writing Techniques & 3 \\
2.7. & Not Using a Rich Vocabulary & 5 \\
Revising and editing & 6 \\
3.1. Not Receiving Feedback & 3 \\
3.2. $\quad$ Inability to Employ a Critical Viewpoint & 3 \\
\hline
\end{tabular}

The reasons for writing inefficacies were classified under the headings of "prewriting", "draft" and "revising and editing", as it was done for the other qualitative questions. In the analysis made based on the answers given by the preservice teachers, the primary sources of this inefficacy in the prewriting stage were identified as "lack of knowledge and experience" ( $f=13)$, "lack of reading habit" $(f=10)$ and as for the draft stage the source of inefficacy was stated to be "not trying" $(f=7)$. Apart from these, referring to affective factors such as having an interest, feeling confident etc. as other sources of inefficacy in writing reveals also the dimensions of attitude and anxiety felt in the writing process. Overall, the major reason for the inefficacies experienced in writing was stated to be caused by prewriting stage $(f=47)$. 


\section{Discussion and Conclusion}

This research was conducted in light of the data obtained from the preservice Turkish teachers studying in the field of language teaching in their first year and in their last year. When the findings obtained in pretest (first year) and posttest (fourth year) administered to the participant preservice teachers were examined, it was concluded that there was a significant difference in favor of the last-year students regarding the WSPS scores they had obtained. When sub-factors of WSPS were elaborated on, the scores obtained in prewriting and draft stages showed a significant difference, again, in favor of the last-year students. However, there was no significant difference observed in the scores obtained in revising and editing stage. Therefore, it would be safe to say that writing self-efficacy perceptions of preservice teachers increased in prewriting and draft factors throughout their education and such improvement is important for seeing that education actually had a positive influence over their writing performance.

Results of a body of research show that writing is directly interrelated to self-efficacy. Self-efficacy beliefs play a predictive and mediating role on the writing performance. The studies conducted up to date with a variety of participants ranging from primary school students to university students show that self-efficacy is an important determinant of writing performance (Pajares, 2003). There exists a good deal of research shedding a light on the fact that carrying out writing exercises for a certain period of time and based on the class variable actually increase writing self-efficacy. For example, Hetthong and Teo (2013) detected that there was high and positive correlation between writing self-efficacy and writing performances of students. Xu and et al., (2011) concluded at the end of their research that digital story writing positively affected the writing self-efficacy of the students. And in a research carried out by Nicolaidou (2012) regarding writing performance, it was concluded that while portfolio-based writing exercises made a significant change in the writing self-efficacy of students, there was no significant change in the writing self-efficacy of those in the control group. The same study revealed that the writing self-efficacy of students progressively increased. Nicolaidou (2012, p. 21) also determined that when students wrote based on portfolio; their self-perceptions in mastery experience with regard to writing self-efficacy, monitoring the process, self-assessment and goal-setting were also enhanced.

Increase in writing self-efficacy is also important in terms of predicting writing anxiety. Among the reasons for writing inefficacy is the emphasized lack of confidence which points out to the correlation between anxiety and self-efficacy. Numerous researches in the literature show a reverse correlation between writing self-efficacy and writing anxiety. Pajares (2003) shows anxiety as one of the factors that affects the writing self-efficacy beliefs. In a research conducted by Martinez, Kock and Cass (2011), the findings revealed that students with lesser level of anxiety had a higher level of writing self-efficacy as compared to the students that had a higher level of anxiety. Woodrow (2011) determined in her study conducted on university students that self-efficacy level was a strong predictor of writing performance and writing anxiety and students with a higher level of selfefficacy had showed better performance and they were more willing to exert effort in writing. Similar results were obtained in the research conducted on university students by Sanders-Reio, Alexander, Reio and Newmana (2014). According to this study, it was observed that those whose writing self-efficacy was better, had less writing anxiety, they were happier when they were writing, and they had better marks on their exam papers. 
The participants produced less number of codes in revising and editing for the question of "What are the gains you acquired in writing during your education?" $(f=26)$; whereas more codes were produced in prewriting $(f=63)$ and draft $(f=177)$ in terms of the gains acquired. It would be safe to say that it is only natural for preservice teachers to state opinions on making preparations and planning in prewriting stage; and on techniques of expression, style, content and grammar in draft stage. In this sense, one could posit that the act of writing in draft stage requires the informed use of a wide range of knowledge and experience by taking account of cognition and metacognition elements. The participants who usually had a higher level of self-efficacy did not show any significant difference in terms of revising and editing during their education (pretest and posttest). As the qualitative findings also support this fact, it can be asserted that this stage is not attached importance as much as the other two stages or it is rather being neglected. Moreover, the answers given by the participants about their own inefficacies $(f=7)$ and about the reasons of these inefficacies $(f=6)$ also had a lower frequency for revising and editing factor. This finding shows that the education process cannot raise the awareness of preservice teachers on feedback, revising and editing. Revising and editing stage is, above all, directly related to the metacognitive dimension of writing. There is a body of literature about the role of metacognition and its effect on writing process. We can list some of the relevant studies as follows: Thinking about people thinking about people thinking about ... (Miller, Kessel \& Flavell, 1970), Students' Metacognitive Knowledge about Writing (Raphael, Englert \& Kirschner, 1989); Developmental skills related to writing and reading acquisition in the intermediate grades (Berninger et al., 1994); Young children's (preschool, ages 3-5) knowledge about thinking (Flavell, Green, Flavell, Harris \& Astington, 1995); Assessment of planning, translating, and editing in junior high writers (Berninger et al., 1996); Developing knowledge about mental uncontrollability (Flavell, Green \& Flavell, 1998); Cognitive, metacognitive, and motivational aspects of problem solving (Mayer, 1998) and children's knowledge about the mind (Flavell, 1999). In light of these studies conducted, it could be concluded that in terms of improving writing skill, the writing encompasses cognitive and metacognitive process that needs to be emphasized, improved, controlled and corrected if needed, rather than psychomotor elements.

The problems related to revising and editing are at the center of many researches in the literature (Beal, 1996; Berninger et al., 1996; Butterfield et al., 1996; Fitzgerald, 1987; Ekholm et al., 2015; Fitzgerald \& Markham, 1987; Grejda \& Hannafin, 1992; Guénette, 2007; Hill, 2007; Hull, 1987; Kellog, 1987; Parr \& Timperley, 2010; Piolat \& Roussey, 1991; Tierney, 1989). Not having an increased level of self-efficacy in revising and editing stage may point out the possible setbacks that might be experienced in teaching of writing phases when and if these preservice teachers start their profession with problems in their own writing skills.

To conclude, at cognitive level, the act of writing necessitates the conveying of experiences in "prewriting", "draft" and "revising and editing", whereas at metacognitive level, it requires full control, review of and intervention to -if necessary- the whole writing process. This primarily relies upon the awareness of the learning individuals. When it is considered that writing is a difficult process with all its cognitive (knowledge and experiences), affective (motivation, attitude, anxiety etc.), psychomotor (act of writing) and metacognitive (control, review) elements, the self-efficacy level should be enhanced including all its stages (prewriting, draft and revising and editing). Therefore, planned writing exercises should be allocated more time beginning from primary school. 
In view of the research findings, it is seen that the participants' overall level of self-efficacy increased at the end of their education although certain inefficacies were experienced in the stages of writing. From this aspect, the results obtained from WSPS support the findings acquired through the analysis of answers given in the interview form. Since these preservice teachers will be teaching language as a profession and therefore are expected to have developed language skills as well as to have teaching skills, it is of high importance for the efficiency of the education that they have an increased level of self-efficacy.

Continuing studies such as this one and correlating them to different variables (anxiety, attitude, academic self, success etc.) for detecting the problems faced in writing in preservice stage plays important role in terms of identifying the factors that affect and predict the writing stage. Furthermore, similar studies can be carried out for preservice Turkish teachers studying in other universities and comparative analyses can be conducted in this regard.

\section{References}

Abrami, P. C. \& Barrett, H. (2005). Directions for research and development on electronic portfolios. Canadian Journal of Learning and Technology, 31(3), 1-15. https://www.learntechlib.org/p/43165/

Aydın, İ.S.; İnnalı, H.Ö.;Batar, M. \& Çakır, H. (2013). Öğretmen adaylarının yazılı anlatım öz yeterliklerine ilişkin ölçek geliştirme çalışması. Journal of Turkish Studies, 8 (8), 139-160.

Beal, C. R. (1996). The role of comprehension monitoring in children's revision. Educational Psychology Review, 8(3), 219-238.

Bayat, N. (2014). Sürece dayalı yazma yaklaşımının yazma başarısı ve kaygısı üstündeki etkisi. Educational Sciences: Theory \& Practice, 14(3), 1123-1141.

Berninger, V. W., Cartwright, A. C., Yates, C. M., Swanson, H. L. \& Abbott, R. D. (1994). Developmental skills related to writing and reading acquisition in the intermediate grades. Reading and Writing, 6(2), 161-196. https://link.springer.com/article/10.1007/BF01026911

Berninger, V., Whitaker, D., Feng, Y., Swanson, H. L., \& Abbott, R. D. (1996). Assessment of planning, translating, and revising in junior high writers. Journal of School Psychology, 34(1), 23-52. https://dx.doi.org/10.1016/0022-4405(95)00024-0

Bruning, R., Dempsey, M., Kauffman, D. F., McKim, C., \& Zumbrunn, S. (2013). Examining dimensions of self-efficacy for writing. Journal of Educational Psychology, 105(1), 25-38. http://dx.doi.org/10.1037/a0029692

Butterfield, E. C., Hacker, D. J., \& Albertson, L. R. (1996). Environmental, cognitive, and metacognitive influences on text revision: Assessing the evidence. Educational Psychology Review, 8(3), 239-297. https://link.springer.com/article/10.1007/BF01464075

Cole, D. J., Ryan, C. W. \& Kick, F. (1995). Portfolios across the curriculum and beyond. Thousand Oaks, CA: Corwin Press, Inc.

Creswell, John W. (2016). Araştırma deseni: nitel, nicel ve karma yöntem yaklaşımları (Ed. S. B. Demir, Çev.). Ankara: Eğiten Kitap. 
Ekholm, E., Zumbrunn, S. \& Conklin, S. (2015). The relation of college student self-efficacy toward writing and writing self-regulation aptitude: writing feedback perceptions as a mediating variable. Teaching in Higher Education, 20 (2), 197-207. http://dx.doi.org/10.1080/13562517.2014.974026

Fitzgerald, J. (1987). Research on revision in writing. Review of Educational Research, 57(4), 481-506. https://dx.doi.org/10.3102/00346543057004481

Fitzgerald, J. \& Markham, L. R. (1987). Teaching children about revision in writing. Cognition and Instruction, 4(1), 3-24. https://dx.doi.org/10.1207/s1532690xci0401_1

Flavell, J. H. (1976). Metacognitive aspects of problem solving. In L. B. Resnick (Ed.), The Nature of Intelligence. 231-235, Hillsdale, NJ: Erlbaum.

Flavell, J. H. (1978). Metacognitive development. In J.M. Scandurave Ch.J. Brainerd (Eds.) Structural process theories of complex human behavior, pp. 34-78. Alphenaan den Rijin: Sitjhoff ve Noorddhoff.

Flavell, J. H. (1981). Cognitive monitoring. In W.P. Dickson (Ed.) Children's oral communications skills (pp. 35-60). NY: Academic Press.

Flavell, J. H. (1982). On Cognitive Development. Child Development, 53(1), 1-10. https://dx.doi.org/ $10.2307 / 1129634$

Flavell, J. H., Green, F. L., Flavell, E. R., Harris, P. L., \& Astington, J. W. (1995). Young children's knowledge about thinking. Monographs of the society for research in child development, 60(1), i-113. https://dx.doi.org/ $10.2307 / 1166124$

Flavell, J. H. (1999). Cognitive development: children's knowledge about the mind. Annual Review of Psychology, 50(1), 21-45. https://dx.doi.org/10.1146/annurev.psych.50.1.21

Flavell, J. H. (2004). Theory-of-mind development: Retrospect and prospect. Merrill-Palmer Quarterly, 50(3), 274-290.

Flavell, J. H.; Green, F. L. \& Flavell, E. R. (1998). The mind has a mind of its own: developing knowledge about mental uncontrollability. Cognitive Development, 13(1), 127-138.

Flower, L.; Hayes, J. R.; Carey, L.; Schriver, K. \& Stratman, J. (1986). Detection, diagnosis, and the strategies of revision. College Composition and Communication, 37(1), 16-55. https://dx.doi.org/10.2307/357381

Grejda, G. F. \& Hannafin, M. J. (1992). Effects of word processing on sixth graders' holistic writing and revisions. The Journal of Educational 144-149. https://dx.doi.org/10.1080/00220671.1992.9944430

Guénette, D. (2007). Is feedback pedagogically correct? Research design issues in studies of feedback on writing. Journal of Second Language Writing, 16, 40-53. https://dx.doi.org/10.1016/j.jslw.2007.01.001

Güneş, F. (2013). Türkçe ögretimi yaklaşımlar ve modeller. Ankara: Pegem A Yayıncılık.

Harrington, M.; Holik, M. \& Hurt, P. (1998). Improving writing through the use of varied strategies. An Action Research Project Submitted to the Graduate Faculty of the School of Education in Partial Fulfillment of the Requirements for the Degree of Master of Arts in Teaching and Leadership. Saint Xavier Universityve IRI/Skylight Field-Based Masters Program Chicago, Illinois May, 1998.

Hetthong, R \& Teo, A. (2013). Does writing self-efficacy correlate with and predict writing performance? International Journal of Applied Linguisticsve English Literature, 2 (1), 157-167. 
Hill, G. (2007). Making the Assessment Criteria Explicit through writing feedback: A pedagogical approach to developing academic writing. International Journal of Pedagogies and Learning, 3 (1), 59-66. https://dx.doi.org/10.5172/ijpl.3.1.59

Hull, G. (1987). The editing process in writing: A performance study of more skilledand less skilled college writers. Research in the Teaching of English, 21(1), 8-29.

Jones, I. \& Pellegrini, A. D. (1996). The effects of social relationships, writing media, and microgenetic development on first-grade students' written narratives. American Educational Research Journal, 33(3), 691-718. https://dx.doi.org/10.3102/00028312033003691

Kellog, R. T. (1987). Effects of topic knowledge on the allocation of processing time and cognitive effort to writing processes. Memory ve Cognition, 15(3), 256-266.

MacArthur, C. A. \& Graham, S. (2016). Writing research from a cognitive perspective. Handbook of Writing Research (Edited by Charles A. MacArthur, Steve Graham, and Jill Fitzgerald.), Second Edition, 24-40, The Guilford Press: New York.

Martinez, C. T.; Kock, N. \& Cass, J. (2011). Painand pleasure in short essay writing: factors predicting university students' writing anxiety and writing self efficacy. Journal of Adolescent ve Adult Literacy. 54(5) 351-360. https://dx.doi.org/10.1598/JAAL.54.5.5

Mayer, R. E. (1998). Cognitive, metacognitive, and motivational aspects of problem solving. Instructional Science, 26(1-2), 49-63.

Miles, M, B., \& Huberman, A. M. (1994). Qualitative data analysis: An expanded sourcebook. (2nd ed). Thousand Oaks, CA: Sage.

Miller, P. H.; Kessel, F. S. \& Flavell, J. H. (1970). Thinking about people thinking about people thinking about...: A study of social cognitive development. Child Development, 41(3), 613-623. https://dx.doi.org/10.2307/1127211

Nicolaidou, I. (2012). Can process portfolios affect students' writing self-efficacy? International Journal of Educational Research, 56, 10-22. https://dx.doi.org/10.1016/j.ijer.2012.08.002

Pajares, F. (2003). Self-efficacy beliefs, motivation, and achievement in writing: A review of the literature. Reading and Writing Quarterly, 19, 139-158. https://dx.doi.org/10.1080/10573560308222

Parr, J. M. \& Timperley, H. S. (2010). Feedback to writing, assessment for teaching and learning and student progress. Assessing Writing, 15, 68-85. https://dx.doi.org/10.1016/j.asw.2010.05.004

Patton, M.Q. (2002). Qualitative research and evaluation methods (3rd Ed.). London: Sage Publications, Inc.

Piolat, A. \& Roussey, J. Y. (1991). Narrativeand descriptive text editing strategies and procedures. European Journal of Psychology of Education, 6(2), 155-163.

Plumb, C.; Butterfield, E. C.; Hacker, D. J. \& Dunlosky, J. (1994). Error correction in text. Reading and Writing, 6(4), 347-360. https://dx.doi.org/10.1007/BF01028848

Raphael, T. E.; Englert, C. S. \& Kirschner, B. W. (1989). Students' Metacognitive Knowledge about Writing. Research in the Teaching of English, 23(4), 343-379.

Reeve, R. A. \& Brown, A. L. (1985). Metacognition Reconsidered: Implications for Intervention Research. Journal of Abnormal Child Psychology, 13(3), 343-356. 
Sanders-Reio, J.; Alexander, P. A.; Reio, T. G. \& Newmana, I. (2014). Do students' beliefs about writing relate to their writing self efficacy, apprehension, and performance? Learning and Instruction, 33, 1-11. https://dx.doi.org/10.1016/j.learninstruc.2014.02.001

Schunk, D. H. (2003). Self-efficacy for reading and writing: Influence of modeling, goalsetting, and selfassessment. Reading and Writing Quarterly, 19, 159-172. https://dx.doi.org/10.1080/10573560308219

Strassman, B. K. (1997). Metacognition and reading in children who are deaf: A review of the research. Journal of Deaf Studies and Deaf Education, 2, 140-149.

Tierney, R. J., Soter, A., O'Flahavan, J. F., \& McGinley, W. (1989). The effects of reading and writing upon thinking critically. Reading Research Quarterly, 24(2), 134-173. https://dx.doi.org/10.2307/747862

Turan, M. (2010). Birinci sınıf öğretmenlerinin ses temelli cümle yöntemi ve yazı türlerine ilişkin görüşleri. Milli Eğitim Dergisi, 187, 8-22.

Ülper H. \& Uzun, L. (2009). The Effect of the writing Pragramme Prepared in accocdance with cognitive process model on student success. Elementary Education Online, 8 (3), 651-665.

Walker, B. J. (2003). The cultivation of student self-efficacy in reading and writing. Reading and Writing Quarterly, 19, 173-187. https://dx.doi.org/10.1080/10573560308217

Woodrow, L. (2011). College English writing affect: Self-efficacy and anxiety. System, 39(4), 510-522. https://dx.doi.org/10.1016/j.system.2011.10.017

$\mathrm{Xu}$, Yan; Park, Hyungsung \& Baek, Youngkyun (2011). A new approach toward digital storytelling: an activity focused on writing self efficacy in a virtual learning environment. Journal of Educational Technology ve Society, 14 (4), 181-191.

Zimmerman, B. J. \& Bandura, A. (1994). Impact of self-regulatory influences on writing course attainment. American Educational Research Journal, 31(4), 845-862.

https://dx.doi.org/10.3102/00028312031004845 